\title{
Número de repetições para a comparação de cultivares de milho
}

\author{
Number of replications for the comparison in corn cultivars
}

\author{
Alberto Cargnelutti Filho ${ }^{\mathrm{I} *}$ Lindolfo Storck ${ }^{\mathrm{I}}$ José Paulo Guadagnin ${ }^{\mathrm{II}}$
}

\section{RESUMO}

O objetivo deste trabalho foi determinar o número de medições (repetições) necessárias à predição do desempenho de cultivares de milho (Zea mays L.). Para isso, foram usados os dados de produtividade de grãos de 286 ensaios de competição de cultivares, realizados no Estado do Rio Grande do Sul, nos anos agrícolas 2002/2003, 2003/2004, 2004/2005, 2005/2006, 2006/2007, 2007/2008 e 2008/2009. Para cada ensaio, foi realizada a análise de variância, estimado o coeficiente de repetibilidade e calculado o número de repetições necessárias para predizer o valor real das cultivares, com base no coeficiente de determinação genotípico de 0,80 e 0,90. Ensaios com três e quatro repetições identificam cultivares superiores de milho, em relação à produtividade de grãos, com, respectivamente, 72,40 e $81 \%$ de exatidão no prognóstico de seu valor real.

Palavras-chave: Zea mays L., repetibilidade, seleção, precisão experimental.

\section{ABSTRACT}

The aim of this research was to determine how many evaluations (replications) were necessary to predict the performance of corn (Zea mays L.) cultivars. Grain yield data were used, from 286 cultivar competition trials of corn, carried out in the Rio Grande do Sul State, Brazil, in the crop years of 2002/2003, 2003/2004, 2004/2005, 2005/2006, 2006/2007, $2007 / 2008$ and 2008/2009. For each assay was carried out the analysis of variance, estimated the repeatability coefficient and calculated the number of replications needed to predict the real value of the cultivars, based on genotypic determination coefficient of 0.80 and 0.90. Assays with three and four replications are sufficient to identify superior cultivars of the corn, in relation to the grains yield, with respectively 72.40 and $81 \%$ accuracy of its real value.

Key words: Zea mays L., repeatability, selection, experimental precision.

\section{INTRODUÇÃO}

Ensaios de competição de cultivares são importantes para avaliar o desempenho agronômico destas em diferentes condições ambientais e, normalmente, fazem parte das etapas finais de um programa de melhoramento de plantas. É importante que esses ensaios tenham uma precisão experimental adequada para que as inferências sejam confiáveis. O número adequado de repetições é um, entre os diversos aspectos, que devem ser considerados no planejamento experimental e tem sido um questionamento comum entre os pesquisadores. Nesse sentido, o número adequado de repetições tem sido investigado na cultura do milho (OLIVEIRA et al., 2005; VELINI et al., 2006, CATAPATTI et al., 2008) e, de maneira geral, esses trabalhos têm destacado a melhoria da precisão por meio de um planejamento experimental adequado. Técnicas experimentais, como o dimensionamento do tamanho ótimo de parcela e do número de repetições (RESENDE \& SOUZA JÚNIOR, 1997), o método de amostragem e o tamanho de amostra (SILVA et al., 1998), o uso de bordaduras laterais em milho-verde (ALVES et al., 2000), o adequado número de plantas por parcela (PALOMINO et al., 2000) e a correção da produtividade de grãos de parcelas experimentais (SCHIMILDT et al., 2006), foram consideradas eficientes na melhoria da precisão experimental.

Metodologias para determinar o número de repetições num experimento encontram-se disponíveis

IDepartamento de Fitotecnia, Centro de Ciências Rurais (CCR), Universidade Federal de Santa Maria (UFSM), 97105-900, Santa Maria, RS, Brasil. E-mail: cargnelutti@pq.cnpq.br. *Autor para correspondência.

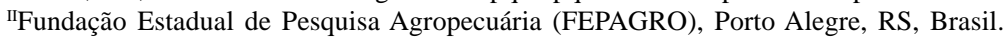


em COCHRAN \& COX (1957), HATHEWAY (1961), GOMES (1990) e STEEL et al. (1997). No entanto, algumas dependem de experimentos específicos e outras são pouco precisas. O dimensionamento do número de repetições, para avaliar a produtividade de grãos, em um grupo de nove ensaios de competição de cultivares de feijão (CARGNELUTTI FILHO et al., 2009) e em um grupo de 216 ensaios e de genótipos de soja (STORCK et al., 2009), tem sido abordado a partir da utilização dos dados experimentais existentes. Essa técnica de análise minimiza custos e aproveita as informações existentes para redefinição ou manutenção de planejamentos experimentais.

Estimativas de coeficiente de repetibilidade, por meio do método da análise de variância (CRUZ, 2006), têm sido obtidas em culturas anuais como o tomateiro (CARGNELUTTI FILHO et al., 2004), o feijão (CARGNELUTTI FILHO et al., 2006, 2009) e a soja (STORCK et al., 2009). A abordagem adotada nesses trabalhos permitiu concluir que: 1) com até sete colheitas, é possível identificar genótipos superiores em relação às características de produção de tomate, com $90 \%$ de exatidão no prognóstico de seu valor real (CARGNELUTTI FILHO et al., 2004); 2) sete experimentos possibilitam a identificação de cultivares superiores de feijão em relação às características de produção, de fenologia e de morfologia, com $85 \%$ de exatidão no prognóstico de seu valor real (CARGNELUTTI FILHO et al., 2006); 3) ensaios com quatro repetições possibilitam a identificação de cultivares superiores de feijão em relação à produtividade de grãos, com $85 \%$ de exatidão no prognóstico de seu valor real (CARGNELUTTI FILHO et al., 2009); e 4) ensaios com quatro repetições e analisados com o método de Papadakis possibilitam a identificação de genótipos superiores de soja em relação à produtividade de grãos, com $80 \%$ de precisão (STORCK et al., 2009). No entanto, nenhuma referência ao emprego da análise de repetibilidade para a estimativa do número de repetições na cultura do milho foi encontrada na literatura consultada.

O objetivo deste trabalho foi determinar o número de medições (repetições) necessárias à predição do desempenho de cultivares de milho, em relação à produtividade de grãos, no Estado do Rio Grande do Sul.

\section{MATERIAL E MÉTODOS}

Foram utilizados os dados de produtividade de grãos, corrigidos a 13\% de umidade, de 286 ensaios de competição de cultivares de milho, realizados no Estado do Rio Grande do Sul. Os ensaios foram classificados em 28 grupos de experimentos conforme a categoria (estadual e indicado), o ciclo (precoce e superprecoce) e o ano agrícola (2002/2003, 2003/2004, 2004/2005, 2005/2006, 2006/2007, 2007/2008 e 2008/2009) (Tabela 1). Em todos os ensaios, utilizou-se o delineamento blocos ao acaso, com três repetições, sendo as unidades experimentais constituídas de duas fileiras com $5 \mathrm{~m}$ de comprimento, com espaçamento entre 0,7 e $0,9 m$.

Em cada ensaio foi realizada a análise de variância, segundo o modelo matemático do delineamento blocos ao acaso (STORCK et al., 2006), e anotadas as estimativas do quadrado médio de cultivar $\left(\mathrm{QM}_{\mathrm{C}}\right)$, do quadrado médio do erro $\left(\mathrm{QM}_{\mathrm{E}}\right)$ e dos resultados dos testes de hipóteses para blocos e cultivares, com 5\% de probabilidade de erro.

Consideraram-se as avaliações em cada bloco como medições realizadas no mesmo indivíduo (cultivar) e estimou-se o coeficiente de repetibilidade (r), em cada ensaio, pelo método da análise de variância. Neste estudo, o coeficiente de repetibilidade é igual ao coeficiente de correlação intraclasse para cultivares e é estimado por meio da expressão

$$
\mathrm{r}=\frac{\left(\mathrm{QM}_{\mathrm{C}}-\mathrm{QM}_{\mathrm{E}}\right) / \mathrm{J}}{\left(\mathrm{QM}_{\mathrm{C}}-\mathrm{QM}_{\mathrm{E}}\right) / \mathrm{J}+\mathrm{QM}_{\mathrm{E}}},
$$

em que J é o número de medições ou repetições (CRUZ \& REGAZZI, 1997; CRUZ, 2006).

O número mínimo de medições ou repetições (J) necessárias para predizer o valor real dos indivíduos (cultivares), com base nos coeficientes de determinação genotípico $\left(\mathrm{R}^{2}\right)$ pré-estabelecidos $\left(\mathrm{R}^{2}=0,80\right.$ e $\left.\mathrm{R}^{2}=0,85\right)$,

foi calculado por meio da expressão $J=\frac{R^{2}(1-r)}{\left(1-R^{2}\right) r}$

(CRUZ \& REGAZZI, 1997). O coeficiente de determinação genotípico $\left(\mathrm{R}^{2}\right)$, que representa a certeza da predição do valor real das cultivares selecionadas com base em J medições

realizadas, foi obtido pela expressão $\mathrm{R}^{2}=\frac{\mathrm{Jr}}{1+\mathrm{r}(\mathrm{J}-1)}$, em que J é o número de medições realizadas ( $\mathrm{J}=3$ blocos neste estudo), e r é o coeficiente de repetibilidade (CRUZ, 2006). As análises e as estimativas foram realizadas com o auxílio do programa GENES (CRUZ, 2006).

\section{RESULTADOS E DISCUSSÃO}

$\mathrm{O}$ teste $\mathrm{F}$ da análise de variância revelou efeito de bloco significativo $(\mathrm{P} \leq 0,05)$ em 120 ensaios (41,96\%), evidenciando blocos heterogêneos e que o uso do delineamento blocos ao acaso foi adequado. 
Tabela 1 - Número de ensaios e número de cultivares de milho avaliadas no Estado do Rio Grande do Sul, em sete anos agrícolas e em diferentes grupos de experimentos.

\begin{tabular}{|c|c|c|c|c|c|}
\hline & ---Grupo d & erimento-- & --- & Número de ensaios & Número de cultivares \\
\hline Número & Categoria $^{(1)}$ & Ciclo & Ano agrícola & (locais) & (em cada local) \\
\hline 1 & Estadual & Precoce & $2002 / 2003$ & 11 & 36 \\
\hline 2 & Estadual & Precoce & $2003 / 2004$ & 12 & 40 \\
\hline 3 & Estadual & Precoce & $2004 / 2005$ & 13 & 32 \\
\hline 4 & Estadual & Precoce & $2005 / 2006$ & 16 & 26 \\
\hline 5 & Estadual & Precoce & $2006 / 2007$ & 14 & 40 \\
\hline 6 & Estadual & Precoce & $2007 / 2008$ & 13 & 60 \\
\hline 7 & Estadual & Precoce & $2008 / 2009$ & 12 & 40 \\
\hline 8 & Estadual & Superprecoce & $2002 / 2003$ & 11 & 11 \\
\hline 9 & Estadual & Superprecoce & $2003 / 2004$ & 12 & 9 \\
\hline 10 & Estadual & Superprecoce & $2004 / 2005$ & 13 & 17 \\
\hline 11 & Estadual & Superprecoce & $2005 / 2006$ & 14 & 23 \\
\hline 12 & Estadual & Superprecoce & $2006 / 2007$ & 14 & 12 \\
\hline 13 & Estadual & Superprecoce & $2007 / 2008$ & 11 & 15 \\
\hline 14 & Estadual & Superprecoce & $2008 / 2009$ & 11 & 26 \\
\hline 15 & Indicado & Precoce & $2002 / 2003$ & 7 & 27 \\
\hline 16 & Indicado & Precoce & $2003 / 2004$ & 8 & 26 \\
\hline 17 & Indicado & Precoce & $2004 / 2005$ & 7 & 30 \\
\hline 18 & Indicado & Precoce & $2005 / 2006$ & 5 & 28 \\
\hline 19 & Indicado & Precoce & $2006 / 2007$ & 9 & 40 \\
\hline 20 & Indicado & Precoce & $2007 / 2008$ & 10 & 30 \\
\hline 21 & Indicado & Precoce & 2008/2009 & 10 & 28 \\
\hline 22 & Indicado & Superprecoce & $2002 / 2003$ & 6 & 18 \\
\hline 23 & Indicado & Superprecoce & $2003 / 2004$ & 8 & 16 \\
\hline 24 & Indicado & Superprecoce & $2004 / 2005$ & 7 & 12 \\
\hline 25 & Indicado & Superprecoce & $2005 / 2006$ & 6 & 12 \\
\hline 26 & Indicado & Superprecoce & $2006 / 2007$ & 9 & 20 \\
\hline 27 & Indicado & Superprecoce & $2007 / 2008$ & 7 & 23 \\
\hline 28 & Indicado & Superprecoce & $2008 / 2009$ & 10 & 14 \\
\hline Total & & & & 286 & \\
\hline
\end{tabular}

(1) Na categoria dos ensaios estaduais, as cultivares avaliadas foram aquelas ainda não indicadas aos produtores, e as indicadas foram estudadas na categoria dos ensaios indicados.

Por outro lado, em 166 ensaios (58,04\%), os blocos não foram heterogêneos. Apesar de, na maioria dos ensaios, ser mais adequado o uso do delineamento inteiramente casualizado, o uso de blocos deve continuar sendo utilizado como uma forma de garantir o controle dessa fonte de heterogeneidade, no caso de sua existência.

Entre os 286 ensaios avaliados, houve efeito de cultivar significativo $(\mathrm{P} \leq 0,05)$ em relação à produtividade de grãos, em 256 ensaios (89,51\%), evidenciando a possibilidade de identificação de cultivares superiores em razão da heterogeneidade do germoplasma avaliado. Nos demais 30 ensaios (10,49\%), a não discriminação das cultivares, por meio do teste $\mathrm{F}$, pode não ser explicada pela não existência de variabilidade genética e sim, provavelmente, pela menor precisão experimental (CARGNELUTTI FILHO \& STORCK, 2007, 2009; RESENDE \& DUARTE, 2007).
Nos 256 ensaios com efeito significativo de cultivares, a média do coeficiente de repetibilidade (r) e do coeficiente de determinação genotípico $\left(\mathrm{R}^{2}\right)$, com base nas três repetições, foi de 0,56 e 0,77 , respectivamente, enquanto que, nos ensaios em que não foram detectadas diferenças significativas, o coeficiente de repetibilidade e o coeficiente de determinação genotípico foram de 0,16 e 0,35. Esses resultados revelam que a não identificação de diferenças entre as cultivares está associada à menor precisão experimental.

As distribuições de frequência dos coeficientes de repetibilidade (r), dos coeficientes de determinação genotípico $\left(\mathrm{R}^{2}\right)$ e do número de repetições (J) associadas aos coeficientes de determinação genotípico de $0,80\left[\mathrm{~J}\left(\mathrm{R}^{2}=0,80\right)\right]$ e 0,85 $\left[\mathrm{J}\left(\mathrm{R}^{2}=0,85\right)\right]$ revelam a possibilidade de o coeficiente de repetibilidade ajustar-se à distribuição normal (Figura 1). 


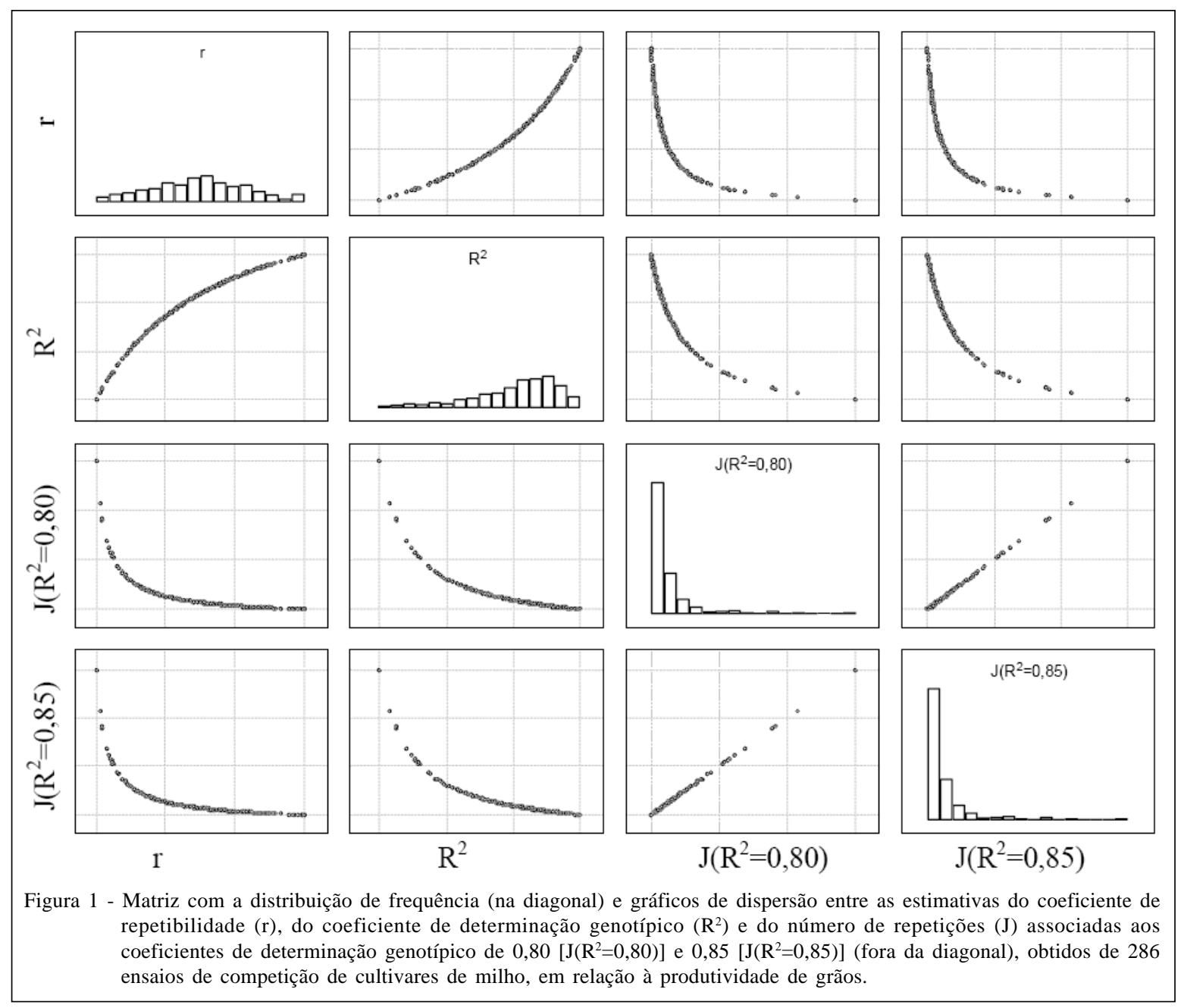

A comprovação dessa visualização foi obtida por meio do teste de normalidade de Lilliefors (SPRENT \& SMEETON, 2007), o qual revelou, a 5\% de probabilidade de erro, que o coeficiente de repetibilidade ajustou-se à distribuição normal de probabilidade. A estatística $\mathrm{R}^{2}$ apresentou assimetria à esquerda (negativa), e as estatísticas $\mathrm{J}\left(\mathrm{R}^{2}=0,80\right)$ e $\mathrm{J}\left(\mathrm{R}^{2}=0,85\right)$ apresentaram assimetria à direita (positiva), o que comprova a rejeição da hipótese de normalidade do teste de Lilliefors. Percebe-se então que entre os 286 ensaios de milho há uma maior frequência de ensaios com valores em torno da média do coeficiente de repetibilidade, com valores elevados de $\mathrm{R}^{2}$, o que resulta em uma maior quantidade de ensaios com estimativa do número de repetições (J) menor. Os ensaios com as maiores estimativas de número de repetições são aqueles com efeito não significativo de cultivares, por meio do teste F (ensaios com menor precisão experimental).

As relações diretas e não lineares entre as estatísticas dos coeficientes de repetibilidade (r), dos coeficientes de determinação $\left(\mathrm{R}^{2}\right)$ e do número de repetições $(\mathrm{J})$ associadas aos coeficientes de determinação de $0,80\left[\mathrm{~J}\left(\mathrm{R}^{2}=0,80\right)\right]$ e $0,85\left[\mathrm{~J}\left(\mathrm{R}^{2}=0,85\right)\right]$ e lineares entre o número de repetições $(\mathrm{J})$ associadas aos coeficientes de determinação de $0,80\left[\mathrm{~J}\left(\mathrm{R}^{2}=0,80\right)\right]$ e $0,85\left[\mathrm{~J}\left(\mathrm{R}^{2}=0,85\right)\right]$ são esperadas e explicadas por seus estimadores (CRUZ, 2006).

A magnitude da estimativa do coeficiente de repetibilidade (r) oscilou entre 0,0472 (um ensaio do grupo 13 - Estadual Superprecoce 2007/2008) e 0,9939 (um ensaio do grupo 3 - Estadual Precoce 2004/2005), com média de 0,5141 (Tabela 2). Ensaios que apresentam menor coeficiente de repetibilidade requerem maior número de medições (repetições) para predizer o valor real de determinado caráter e vice-versa. Além disso, os valores altos do coeficiente de repetibilidade indicam regularidade da superioridade das cultivares de um bloco para outro, dentro do mesmo ensaio e, consequentemente, necessidade de menor número de repetições para realizar a identificação de 
Tabela 2 - Valor mínimo, valor máximo, média, desvio padrão (DP) e coeficiente de variação (CV\%) das estimativas dos coeficientes de repetibilidade $(\mathrm{r})$ e dos coeficientes de determinação genotípico $\left(\mathrm{R}^{2}\right)$ em cada grupo de experimentos de milho.

\begin{tabular}{|c|c|c|c|c|c|c|c|c|c|c|}
\hline \multirow{2}{*}{ Grupo $^{(1)}$} & \multicolumn{5}{|c|}{---------------Coeficientes de repetibilidade (r)--------------- } & \multicolumn{5}{|c|}{------------Coeficientes de determinação $\left(\mathrm{R}^{2}\right)^{(2)}$} \\
\hline & Mínimo & Máximo & Média & DP & CV(\%) & Mínimo & Máximo & Média & DP & CV(\%) \\
\hline 1 & 0,3435 & 0,9626 & 0,6754 & 0,1733 & 25,66 & 0,6108 & 0,9872 & 0,8482 & 0,1044 & 12,30 \\
\hline 2 & 0,1512 & 0,7430 & 0,4805 & 0,2020 & 42,04 & 0,3483 & 0,8966 & 0,7003 & 0,1866 & 26,64 \\
\hline 3 & 0,2283 & 0,9939 & 0,5685 & 0,1907 & 33,55 & 0,4703 & 0,9979 & 0,7773 & 0,1303 & 16,76 \\
\hline 4 & 0,1967 & 0,8623 & 0,4739 & 0,1755 & 37,03 & 0,4235 & 0,9495 & 0,7068 & 0,1398 & 19,78 \\
\hline 5 & 0,2608 & 0,7300 & 0,5082 & 0,1457 & 28,67 & 0,5142 & 0,8902 & 0,7408 & 0,1152 & 15,55 \\
\hline 6 & 0,0647 & 0,7258 & 0,5000 & 0,1892 & 37,84 & 0,1718 & 0,8882 & 0,7175 & 0,1927 & 26,86 \\
\hline 7 & 0,1469 & 0,7193 & 0,4860 & 0,1958 & 40,30 & 0,3406 & 0,8849 & 0,7083 & 0,1731 & 24,44 \\
\hline 8 & 0,2675 & 0,9461 & 0,6711 & 0,2134 & 31,80 & 0,5228 & 0,9814 & 0,8374 & 0,1370 & 16,36 \\
\hline 9 & 0,0770 & 0,9893 & 0,4958 & 0,2166 & 43,69 & 0,2001 & 0,9964 & 0,7111 & 0,1919 & 26,99 \\
\hline 10 & 0,2973 & 0,9836 & 0,6334 & 0,1713 & 27,04 & 0,5593 & 0,9945 & 0,8234 & 0,1091 & 13,24 \\
\hline 11 & 0,2339 & 0,7103 & 0,4450 & 0,1373 & 30,86 & 0,4780 & 0,8803 & 0,6901 & 0,1218 & 17,65 \\
\hline 12 & 0,1163 & 0,8310 & 0,4391 & 0,2786 & 63,44 & 0,2831 & 0,9365 & 0,6290 & 0,2669 & 42,43 \\
\hline 13 & 0,0472 & 0,8039 & 0,4351 & 0,2601 & 59,78 & 0,1293 & 0,9248 & 0,6348 & 0,2581 & 40,66 \\
\hline 14 & 0,0769 & 0,8027 & 0,4985 & 0,2090 & 41,92 & 0,2000 & 0,9243 & 0,7088 & 0,2160 & 30,48 \\
\hline 15 & 0,3651 & 0,8323 & 0,5734 & 0,1518 & 26,47 & 0,6331 & 0,9371 & 0,7894 & 0,0991 & 12,55 \\
\hline 16 & 0,3146 & 0,9739 & 0,6365 & 0,2157 & 33,88 & 0,5793 & 0,9911 & 0,8178 & 0,1362 & 16,66 \\
\hline 17 & 0,2101 & 0,8840 & 0,5863 & 0,2137 & 36,44 & 0,4439 & 0,9581 & 0,7822 & 0,1668 & 21,32 \\
\hline 18 & 0,4096 & 0,9897 & 0,6083 & 0,2253 & 37,03 & 0,6755 & 0,9966 & 0,8039 & 0,1206 & 15,00 \\
\hline 19 & 0,0757 & 0,8330 & 0,4393 & 0,2362 & 53,78 & 0,1972 & 0,9374 & 0,6518 & 0,2297 & 35,23 \\
\hline 20 & 0,0976 & 0,5334 & 0,3809 & 0,1324 & 34,76 & 0,2449 & 0,7742 & 0,6277 & 0,1574 & 25,08 \\
\hline 21 & 0,1654 & 0,7386 & 0,5012 & 0,1724 & 34,39 & 0,3728 & 0,8945 & 0,7270 & 0,1566 & 21,54 \\
\hline 22 & 0,1671 & 0,8563 & 0,4915 & 0,2932 & 59,65 & 0,3758 & 0,9470 & 0,6866 & 0,2357 & 34,33 \\
\hline 23 & 0,3377 & 0,9876 & 0,6717 & 0,2278 & 33,92 & 0,6047 & 0,9958 & 0,8362 & 0,1408 & 16,83 \\
\hline 24 & 0,5092 & 0,9374 & 0,6845 & 0,1368 & 19,98 & 0,7569 & 0,9782 & 0,8599 & 0,0706 & 8,21 \\
\hline 25 & 0,1782 & 0,9920 & 0,3892 & 0,3027 & 77,77 & 0,3941 & 0,9973 & 0,5971 & 0,2128 & 35,64 \\
\hline 26 & 0,1078 & 0,9195 & 0,3911 & 0,2741 & 70,09 & 0,2660 & 0,9717 & 0,5895 & 0,2593 & 43,98 \\
\hline 27 & 0,2369 & 0,5651 & 0,3669 & 0,1067 & 29,07 & 0,4822 & 0,7958 & 0,6243 & 0,1009 & 16,17 \\
\hline 28 & 0,2018 & 0,7720 & 0,4642 & 0,1905 & 41,03 & 0,4313 & 0,9104 & 0,6950 & 0,1557 & 22,40 \\
\hline
\end{tabular}

${ }^{(1)}$ Grupo de experimentos definidos na tabela $1 .{ }^{(2)}$ Estimados com base em três repetições.

uma cultivar superior. Valores altos (próximos de um) de estimativas de repetibilidade para determinado caráter indicam que é viável predizer o valor real do indivíduo, utilizando-se um número relativamente pequeno de medições, ocorrendo o inverso quando a repetibilidade é baixa (próxima de zero) (CRUZ \& REGAZZI, 1997).

Entre os 28 grupos de experimentos, a média do coeficiente de repetibilidade (r) oscilou entre 0,3669 (grupo 27 - Indicado Superprecoce 2007/2008) e 0,6845 (grupo 24 - Indicado Superprecoce 2004/2005) (Tabela 2). Com base nesse mesmo método, CARGNELUTTI FILHO et al. (2009) obtiveram estimativas do coeficiente de repetibilidade (r) da produtividade de grãos de feijão entre 0,28 e 0,82 , e a média dos nove ensaios de 14 cultivares foi de 0,53 . Concluíram que, para a região da depressão central do Estado do Rio Grande do Sul, ensaios com quatro repetições identificam cultivares de feijão superiores, em relação à produtividade de grãos, com 85\% de exatidão no prognóstico de seu valor real. Os resultados de produtividade de grãos de soja de 216 ensaios de competição de genótipos realizados no Estado do Rio Grande do Sul e executados no delineamento blocos ao acaso, com número de repetições variando entre três e quatro e de genótipos, entre 10 e 20, foram utilizados em estudo de STORCK et al. (2009). Esses autores obtiveram estimativas do coeficiente de repetibilidade (r) entre 0,0470 e 0,8214, com média de 0,3829 , e concluíram que ensaios com as usuais quatro repetições, analisados com o método de Papadakis, possibilitam a identificação de genótipos superiores de soja em relação à produtividade de grãos, com $80 \%$ de precisão. No entanto, sem a utilização do método de Papadakis, 11 repetições seriam necessárias para essa mesma precisão. 
Os coeficientes de determinação genotípico $\left(\mathrm{R}^{2}\right)$ associados às estimativas dos coeficientes de repetibilidade (r) oscilaram entre 0,1293 (um ensaio do grupo 13 - Estadual Superprecoce 2007/2008) e 0,9979 (um ensaio do grupo 3 - Estadual Precoce 2004/2005), com média de 0,7240 (Tabela 2). Assim, pode-se inferir que três repetições possibilitam detectar diferenças genotípicas com 12,93\% ou mais de certeza na predição do valor real da cultivar (Tabela 2). Além disso, em média, as atuais três repetições, utilizadas nesses 286 ensaios, possibilitaram detectar diferenças genotípicas com 72,40\% de certeza na predição do valor real da cultivar. Em relação à produtividade de grãos de 14 cultivares de feijão avaliadas em nove ensaios, a média do coeficiente de determinação genotípico foi de 0,7423 (CARGNELUTTI FILHO et al., 2009). Entre os 28 grupos de experimentos, a média do coeficiente de determinação genotípico $\left(R^{2}\right)$ oscilou entre 0,5895 (grupo 26 - Indicado
Superprecoce 2006/2007) e 0,8599 (grupo 24 - Indicado Superprecoce 2004/2005) (Tabela 2).

De maneira geral, diante dos resultados dos valores mínimo e máximo, da média, do desvio padrão e do coeficiente de variação, pode-se inferir que há variabilidade das estimativas dos coeficientes de repetibilidade (r) e dos coeficientes de determinação genotípico $\left(R^{2}\right)$ entre os 286 ensaios e ainda entre os ensaios em cada grupo de experimentos de milho (Tabela $2)$. Isso reflete em variabilidade no número de repetições para um mesmo valor de $\mathrm{R}^{2}$ (Tabela 3 ), o que sugere que há necessidade de aplicação de planejamentos experimentais específicos por ensaio ou por grupo de experimentos. No entanto, essa variabilidade das estimativas dos coeficientes de repetibilidade e dos coeficientes de determinação genotípico (Tabela 2) e do número de repetições (Tabela 3) entre os 286 ensaios ou entre ensaios de um mesmo

Tabela 3 - Valor mínimo, valor máximo, média, desvio padrão (DP) e coeficiente de variação (CV\%) das estimativas do número de medições (repetições) $^{(2)}$ associadas a diferentes coeficientes de determinação genotípico $\left(\mathrm{R}^{2}\right)$ em cada grupo de experimentos de milho.

\begin{tabular}{|c|c|c|c|c|c|c|c|c|c|c|}
\hline \multirow{2}{*}{ Grupo $^{(1)}$} & \multicolumn{5}{|c|}{-----------Número de repetições $\left(\mathrm{R}^{2}=0,80\right)$------------ } & \multicolumn{5}{|c|}{------------Número de repetições $\left(\mathrm{R}^{2}=0,85\right)$------------ } \\
\hline & Mínimo & Máximo & Média & DP & CV(\%) & Mínimo & Máximo & Média & DP & $\mathrm{CV}(\%)$ \\
\hline 1 & 0,16 & 7,65 & 2,38 & 2,06 & 86,86 & 0,22 & 10,83 & 3,37 & 2,92 & 86,86 \\
\hline 2 & 1,38 & 22,45 & 6,74 & 6,74 & 100,02 & 1,96 & 31,80 & 9,55 & 9,55 & 100,02 \\
\hline 3 & 0,02 & 13,52 & 3,93 & 3,33 & 84,62 & 0,04 & 19,15 & 5,57 & 4,72 & 84,62 \\
\hline 4 & 0,64 & 16,34 & 5,69 & 3,98 & 69,88 & 0,90 & 23,14 & 8,07 & 5,64 & 69,88 \\
\hline 5 & 1,48 & 11,34 & 4,62 & 2,96 & 64,15 & 2,10 & 16,06 & 6,55 & 4,20 & 64,15 \\
\hline 6 & 1,51 & 57,84 & 8,17 & 15,10 & 184,78 & 2,14 & 81,94 & 11,58 & 21,40 & 184,78 \\
\hline 7 & 1,56 & 23,24 & 6,27 & 6,24 & 99,44 & 2,21 & 32,92 & 8,89 & 8,84 & 99,44 \\
\hline 8 & 0,23 & 10,95 & 2,78 & 3,09 & 111,16 & 0,32 & 15,52 & 3,94 & 4,38 & 111,16 \\
\hline 9 & 0,04 & 47,96 & 7,78 & 12,83 & 164,87 & 0,06 & 67,95 & 11,02 & 18,17 & 164,87 \\
\hline 10 & 0,07 & 9,46 & 2,86 & 2,36 & 82,64 & 0,09 & 13,40 & 4,05 & 3,34 & 82,64 \\
\hline 11 & 1,63 & 13,10 & 5,97 & 3,55 & 59,53 & 2,31 & 18,56 & 8,45 & 5,03 & 59,53 \\
\hline 12 & 0,81 & 30,39 & 11,85 & 12,46 & 105,09 & 1,15 & 43,06 & 16,79 & 17,65 & 105,09 \\
\hline 13 & 0,98 & 80,83 & 14,29 & 23,47 & 164,23 & 1,38 & 114,51 & 20,25 & 33,25 & 164,23 \\
\hline 14 & 0,98 & 48,00 & 8,54 & 13,88 & 162,47 & 1,39 & 68,00 & 12,10 & 19,66 & 162,47 \\
\hline 15 & 0,81 & 6,96 & 3,42 & 2,02 & 59,12 & 1,14 & 9,85 & 4,84 & 2,86 & 59,12 \\
\hline 16 & 0,11 & 8,71 & 3,08 & 2,84 & 92,23 & 0,15 & 12,35 & 4,37 & 4,03 & 92,23 \\
\hline 17 & 0,53 & 15,03 & 4,22 & 4,93 & 116,82 & 0,74 & 21,30 & 5,98 & 6,99 & 116,82 \\
\hline 18 & 0,04 & 5,77 & 3,18 & 2,11 & 66,43 & 0,06 & 8,17 & 4,50 & 2,99 & 66,43 \\
\hline 19 & 0,80 & 48,86 & 10,61 & 14,94 & 140,78 & 1,14 & 69,21 & 15,03 & 21,16 & 140,78 \\
\hline 20 & 3,50 & 37,00 & 9,28 & 10,04 & 108,21 & 4,96 & 52,41 & 13,15 & 14,23 & 108,21 \\
\hline 21 & 1,42 & 20,19 & 5,56 & 5,60 & 100,81 & 2,01 & 28,60 & 7,87 & 7,94 & 100,81 \\
\hline 22 & 0,67 & 19,93 & 7,62 & 7,72 & 101,35 & 0,95 & 28,24 & 10,80 & 10,94 & 101,35 \\
\hline 23 & 0,05 & 7,84 & 2,76 & 2,82 & 101,95 & 0,07 & 11,11 & 3,91 & 3,99 & 101,95 \\
\hline 24 & 0,27 & 3,85 & 2,04 & 1,15 & 56,38 & 0,38 & 5,46 & 2,88 & 1,63 & 56,38 \\
\hline 25 & 0,03 & 18,45 & 9,86 & 6,21 & 62,97 & 0,05 & 26,13 & 13,97 & 8,80 & 62,97 \\
\hline 26 & 0,35 & 33,12 & 13,07 & 12,59 & 96,39 & 0,50 & 46,91 & 18,51 & 17,84 & 96,39 \\
\hline 27 & 3,08 & 12,88 & 7,65 & 3,14 & 41,03 & 4,36 & 18,25 & 10,84 & 4,45 & 41,03 \\
\hline 28 & 1,18 & 15,82 & 6,17 & 4,63 & 75,03 & 1,67 & 22,42 & 8,75 & 6,56 & 75,03 \\
\hline
\end{tabular}

${ }^{(1)}$ Grupo de experimentos definidos na tabela $1 .{ }^{(2)}$ Estimativas menores que um devem ser interpretadas como um. 
grupo de experimentos e ainda entre os ensaios em um mesmo local em diferentes anos agrícolas torna difícil um planejamento experimental específico. Nesse sentido, uma abordagem geral que contemple de forma satisfatória um maior conjunto de ensaios parece adequada. Neste estudo, foram mantidos os ensaios que normalmente seriam descartados por insuficiência de precisão experimental. Esses ensaios reduzem as estimativas de médias do $\mathrm{r}$ e do $\mathrm{R}^{2} \mathrm{e}$ aumentam as estimativas de médias do número de repetições. Particularmente, isso é importante, pois a média estimada do número de repetições necessárias para um determinado $\mathrm{R}^{2}$ incluindo esses ensaios, que deveriam ser descartados, oferece uma maior segurança, ou seja, são ensaios mais precisos que o proposto.

Em relação à produtividade de grãos, considerando o coeficiente de repetibilidade (média dos 286 ensaios $=0,5141)$, seriam necessárias 5,35 repetições, ou seja, $\mathrm{J}\left(\mathrm{R}^{2}=0,85\right)=0,85(1-0,5141) /(1$ $0,85) 0,5141=5,35$, ou 3,78 repetições, ou seja, $\mathrm{J}\left(\mathrm{R}^{2}=0,80\right)$ $=0,80(1-0,5141) /(1-0,80) 0,5141=3,78$, para afirmar-se, respectivamente, com 85 e $80 \%$ de precisão, a superioridade de uma determinada cultivar, para as condições do Estado do Rio Grande do Sul. Do ponto de vista prático, não é possível conduzir ensaios com 5,35 ou com 3,78 repetições. Assim, fazendo o cálculo inverso, a partir de $\mathrm{J}=4$ repetições, o valor estimado do coeficiente de determinação genotípico é $\mathrm{R}^{2}=(4 * 0,5141) / 1+0,5141(4-1)=0,81$. Para ensaios de Valor de Cultivo e Uso (VCU), o uso de ao menos seis repetições para se conseguir acurácia seletiva (iguais ou superiores a 90\%) tem sido proposto por RESENDE \& DUARTE (2007), o que equivale a coeficientes de determinação genotípico iguais ou superiores a $81 \%$.

Neste estudo, ficou demonstrado que há variabilidade do número de repetições entre os ensaios. No entanto, considerando um valor médio para o coeficiente de repetibilidade, pode-se inferir que é possível identificar cultivares superiores, em relação à produtividade de grãos, com precisão de $81 \%$, com quatro repetições. Assim, diante dos resultados desse conjunto de ensaios, pode-se inferir que a continuidade da realização dos ensaios de competição de cultivares de milho, no delineamento blocos ao acaso, e o aumento do número de repetições de três para quatro, são procedimentos adequados para serem atingidas metas de acurácia seletiva de 90\% (RESENDE \& DUARTE, 2007), o que confere precisão experimental muito alta (CARGNELUTTI FILHO \& STORCK, 2007, 2009; RESENDE \& DUARTE, 2007).

\section{CONCLUSÃO}

No Estado do Rio Grande do Sul, ensaios com três e quatro repetições identificam cultivares superiores de milho, em relação à produtividade de grãos, com, respectivamente, 72,40 e 81\% de exatidão no prognóstico de seu valor real.

\section{AGRADECIMENTOS}

Ao Conselho Nacional de Desenvolvimento Científico e Tecnológico (CNPq), pela concessão de bolsa de Produtividade em Pesquisa para Alberto Cargnelutti Filho e Lindolfo Storck; à Fundação Estadual de Pesquisa Agropecuária; e aos pesquisadores, pela realização dos ensaios de competição de cultivares de milho no Estado do Rio Grande do Sul.

\section{REFERÊNCIAS}

ALVES, S. M. de F. et al. Diferentes arranjos para estudo de bordadura lateral em parcelas experimentais de milho-verde. Pesquisa Agropecuária Brasileira, v.35, p.2145-2150, 2000. Disponível em: <http://www.scielo.br/scielo.php?script=sci_arttext\&pid=S0100204X2000001100004\&lng=en\&nrm=iso> Acesso em: 3 fev. 2010. doi: 10.1590/S0100-204X2000001100004.

CARGNELUTTI FILHO, A. et al. Número de colheitas e comparação de genótipos de tomateiro cultivados em estufa de plástico. Pesquisa Agropecuária Brasileira, v.39, p.953959, 2004. Disponível em: <http://www.scielo.br/ s c i elo.ph p ? s c ri p t = s c i_art text \& pid = S $0100-$ 204X2004001000002\&lng=pt\&nrm=iso $>$ Acesso em: 25 ago. 2009. doi: 10.1590/S0100-204X2004001000002.

CARGNELUTTI FILHO, A. et al. Número de repetições para a comparação de cultivares de feijão. Ciência Rural, v.39, p.2419-2424, 2009. Disponível em: <http://www.scielo.br/ s ci el o.ph p ? s c ri p t = sci_art text \& pid = S 0103 84782009000900006\&lng=en\&nrm=iso $>$ Acesso em: 3 fev. 2010. doi: 10.1590/S0103-84782009000900006.

CARGNELUTTI FILHO, A. et al. Número necessário de experimentos para a comparação de cultivares de feijão. Ciência Rural, v.36, p.1701-1709, 2006. Disponível em: <http:// www.scielo.br/scielo.php?script=sci_arttext\&pid=S0103$84782006000600006 \& \operatorname{lng}=$ pt\&nrm=iso $>$ Acesso em: 25 ago. 2009. doi: 10.1590/S0103-84782006000600006.

CARGNELUTTI FILHO, A.; STORCK, L. Estatísticas de avaliação da precisão experimental em ensaios de cultivares de milho. Pesquisa Agropecuária Brasileira, v.42, p.17-24, 2007. Disponível em: $<$ http://www.scielo.br/scielo.php?script=sci_arttext\&pid=S0100204X2007000100003\&lng=pt\&nrm=iso> Acesso em: 25 ago. 2009. doi: 10.1590/S0100-204X2007000100003.

CARGNELUTTI FILHO, A.; STORCK, L. Medidas do grau de precisão experimental em ensaios de competição de cultivares de milho. Pesquisa Agropecuária Brasileira, v.44, p.111-117, 2009. Disponível em: $<$ http://www.scielo.br/scielo.php?script=sci_arttext\&pid=S0100204X2009000200001\&lng=pt\&nrm=iso> Acesso em: 25 ago. 2009. doi: 10.1590/S0100-204X2009000200001. 
CATAPATTI, T.R. et al. Tamanho de amostra e número de repetições para avaliação de caracteres agronômicos em milho-pipoca. Ciência e Agrotecnologia, v.32, p.855-862, 2008. Disponível em: <http:/ /www.scielo.br/scielo.php?script=sci_arttext\&pid=S141370542008000300023\&lng=pt\&nrm=iso> Acesso em: 25 ago. 2009. doi: 10.1590/S1413-70542008000300023.

COCHRAN, W.G.; COX, G.M. Experimental design. 2.ed. New York: John Wiley, 1957. 611p.

CRUZ, C.D. Programa Genes: Biometria. Viçosa: UFV, 2006. 382p.

CRUZ, C.D.; REGAZZI, A.J. Modelos biométricos aplicados ao melhoramento genético. 2.ed. Viçosa: UFV, 1997. 390p.

GOMES, F.P. Curso de estatística experimental. 13.ed. Piracicaba: São Paulo: Nobel 1990. 468p.

HATHEWAY, W.H. Convenient plot size. Agronomy Journal, v.53, p.279-280, 1961.

OLIVEIRA, S.J.R. de et al. Substituindo o uso de bordaduras laterais por repetições em experimentos com milho. Ciência Rural, v.35, p.10-15, 2005. Disponível em: <http:// www.scielo.br/scielo.php?script=sci_arttext\&pid=S010384782005000100003\&lng=pt\&nrm=iso> Acesso em: 25 ago. 2009. doi: 10.1590/S0103-84782005000100003.

PALOMINO E.C. et al. Tamanho da amostra para avaliação de famílias de meio-irmãos de milho. Pesquisa Agropecuária Brasileira, Brasília, v.35, p.1433-1439, 2000. Disponível em: <http://www.scielo.br/scielo.php?script=sci_arttext\&pid=S0100204X2000000700018\&lng=en\&nrm=iso $>$ Acesso em: 3 fev. 2010. doi: 10.1590/S0100-204X2000000700018.

RESENDE, M.D.V.; SOUZA JÚNIOR, C.L. Número de repetições e tamanho de parcela para seleção de progênies de milho em solos sob cerrado fértil. Pesquisa Agropecuária Brasileira, Brasília, v.32, p.781-788, 1997.
RESENDE, M.D.V.; DUARTE, J.B. Precisão e controle de qualidade em experimentos de avaliação de cultivares. Pesquisa Agropecuária Tropical, v.37, p.182-194, 2007.

SCHIMILDT, E.R. et al. Melhoria na eficiência dos experimentos de indicação de cultivares de milho. Ciência e Agrotecnologia, v.30, p.72-80, 2006. Disponível em: <http:/ /www.scielo.br/scielo.php?script=sci_arttext\&pid=S1413$70542006000100010 \& \operatorname{lng}=p t \& n r m=i s o \& t \operatorname{lng}=p t>$ Acesso em: 3 fev. 2010. doi: 10.1590/S1413-70542006000100010.

SILVA, J. et al. Amostragem e tamanho de amostra na estimação de caracteres do milho. Pesquisa Agropecuária Brasileira, v.33, p.1983-1988, 1998.

SPRENT, P.; SMEETON, N.C. Applied nonparametric statistical methods. 4.ed. Boca Raton: Chapman \& Hall, 2007. 530p.

STEEL, R.G.D. et al. Principles and procedures of statistics: a biometrical approach. 3.ed. New York: McGraw Hill Book, 1997. 666p.

STORCK, L. et al. Experimentação vegetal. 2.ed. Santa Maria: UFSM, 2006. 198p.

STORCK, L. et al. Método de Papadakis e número de repetições em experimentos de soja. Ciência Rural, v.39, p.977-9820, 2009. Disponível em: <http://www.scielo.br/ s cielo.ph p ? s c ri p t = s ci_art text \& pid=S 0103 $84782009000400004 \& \operatorname{lng}=p t \& n r m=i s o>$ Acesso em: 25 ago. 2009. doi: 10.1590/S0103-84782009005000027.

VELINI, E.D. et al. Interferência de plantas daninhas na cultura do milho: I - efeito do número de repetições sobre a precisão dos resultados obtidos. Planta daninha, v.24, p.435-442, 2006. Disponível em: $<$ http://www.scielo.br/scielo.php?script=sci_arttext\&pid=S010083582006000300003\&lng=pt\&nrm=iso> Acesso em: 25 ago. 2009. doi: 10.1590/S0100-83582006000300003. 